\title{
Avdekket fødselsdepresjon
}

\author{
Edinburgh Postnatal Depression Scale (EPDS) ved 6-ukerskonsultasjonen ga bedre oversikt over mødres \\ psykiske helse.
}

$\mathbf{S}$ måbarnsteamet ved BUP ved sykehuset $\mathrm{i}$ Levanger gjennomførte i perioden 20082011 et prosjekt der målet var å implementere selvvurderingsskalaen Edinburgh Postnatal Depression Scale (EPDS) på helsestasjonene i tre kommuner i Nord-Trøndelag. Gjennom prosjektet ønsket BUP å gi helsesøstrene et kartleggingsverktøy som de kunne bruke i tillegg til klinisk samtale for å avdekke fødselsdepresjon hos mor og gi tilpasset hjelp. Vi ville undersøke om EPDS ble vurdert som et godt hjelpemiddel. Vi var dessuten interessert i å høre hvor fornøyde helsesøstrene var med opplæringen og veiledningen de fikk fra oss.

\section{Mye brukt}

EPDS er en selvvurderingsskala for å screene fødselsdepresjon (1). Den er mye brukt ved helsestasjonene i Europa og i Nord-Amerika og er validert for norske forhold (2). EPDS består av ti områder. Kvinnen skal streke under det svaret som best beskriver hvordan hun har følt seg de siste sju dagene. EPDS kan administreres av helsesøster som har fătt opplæring i bruk av skalaen. Den må alltid kombineres med samtale der man fokuserer

\section{Hovedbudskap}

I denne studien var vi interessert i å undersøke om helsesøstrene vurderte Edinburgh Postnatal Depression Scale (EPDS) som et nyttig hjelpemiddel. Vi var dessuten interessert i å høre om deres erfaring med opplæring og veiledning fra BUP: De fleste helsesøstrene var fornøyd med opplæringa som ble gitt og med veiledninga fra BUP. I vår studie, fant helses $\emptyset$ strene relativt få kvinner med depressive symptomer som de ikke kjente fra før, ca 3,5 \%. De fleste helsesøstrene vil likevel anbefale bruk av EPDS fordi metoden gjør det enklere å rette oppmerksomheten mot kvinnens psykiske helse. Etter at prosjektet ble avsluttet, har kommunene besluttet å fortsette å bruke EPDS.

\section{Nøkkelord}

Les mer og finn litteraturhenvisninger på våre nettsider. \ Helsestasjon \Depresjon \Nyfødt \ Psykisk helse på kvinnens situasjon. EPDS kan administreres seks til åtte uker etter fødsel. Hvis man bruker den for tidlig etter fødsel, vil man få med for mange med vanlige tilpasningsvansker.

I helsesøstrenes veileder heter det at de skal ta opp hvordan kvinnens psykiske helse er ved seksukerskontroll. En undersøkelse blant helsesøstrene i Oslo viste at de hadde vansker med å fange opp kvinner som slet psykisk etter fødselen (3). Kvinner med fødselsdepresjoner tar i liten grad selv opp sine vansker, og få blir derfor oppdaget gjennom vanlige konsultasjoner $(4,5)$.

Forskning viser at de fleste kvinner med fødselsdepresjon kan få tilstrekkelig hjelp gjennom samtaler med helsesøstre. Det er de færreste kvinner som vil trenge hjelp fra spesialisthelsetjenesten (6-8).

\section{Lavere forekomst i Norge}

Tiden etter fødselen er en periode der de fleste kvinner opplever økt psykisk sårbarhet. Denne sårbarheten viser seg på mange måter; fra normal nedstemthet og labilitet til alvorlig sykdomstilstand eller fødselspsykose.

I epidemiologiske studier varierer forekomsten av fødselsdepresjon mellom 0-60 prosent. (9). Hvilket resultat man får synes å avhenge av målemetode, tidspunkt etter fødsel da måling ble foretatt, og av hvordan man definerer depresjon. Flere studier tyder på at forekomst av fødselsdepresjon er lavere i Norge enn i andre land (9). Jeg vil ikke diskutere mulige årsaker til det her, men mye kan tyde på at høy levestandard og gode rettigheter for spedbarnsforeldre spiller inn.

I psykisk helsevern for barn og unge, BUP, er det et mål å oppdage barn og unge som er i fare for å utvikle psykiske vansker og intervenere tidlig. Depresjon hos mor kan være en risikofaktor for barnets psykiske helse $(10,8)$. Det er avgjørende for det lille barnet at omsorgspersonen kan oppfatte og besvare dets signaler. Belastninger i foreldrenes livssituasjon, som for eksempel en depresjon, kan hindre at foreldrene går inn i et sensitivt samspill med barnet sitt. Her er det viktig å understreke at en del deprimerte klarer å opprette et godt samspill med barnet sitt.

\section{Prosjektet}

Helsestasjonene i Levanger og Inderøy startet prosjektet med å implementer EPDS våren 2008. Verdal kommune startet opp i oktober 2008. I tillegg til prosjektleder deltok to helsesøstre og to jordmødre i prosjektet i Verdal. Jordmødrene benyttet EPDS i svangerskapskontroll. I Inderøy ble konsultasjonstiden ved 6-ukerskontroll økt med 10 minutter, fra 30 til 40 minutter, og i Verdal med 15 minutter. I Levanger ble ikke konsultasjonstiden ved 6-ukerskontroll økt.

Det ble holdt oppfølgingskurs i 2008 og i 2009.

\section{Gjennomføring}

Som vi nevnte innledningsvis har flere studier vist at de fleste kvinner som sliter etter fødsel, vil få tilstrekkelig hjelp gjennom støttesamtaler hos helsesøster. Noen vil imidlertid ha behov for å henvises til spesialisthelsetjenesten. For å sikre at de kvinnene som ble henvist videre ble ivaretatt, informerte BUP kommuneoverlegene om prosjektet. Man anbefalte fastlegene å bruke EPDS når de vurderte om kvinnen trengte hjelp for depresjon. BUP hadde også et orienteringsmøte med voksenpsykiatrien (VOP) om prosjektet, og ba om at de prioriterte hjelp til kvinner med fødselsdepresjoner.

Etter kursene avtalte BUP veiledning med helsestasjonene som en oppfølging av kurset. I tillegg tilbød vi oss å være til stede ved konsultasjoner med mor, barn og helsesøster uten henvisning. I noen få tilfeller benyttet helsesøstrene seg av dette tilbudet. Da Levanger fikk ansatt en kommunepsykolog, overtok hun veiledningen.

Alle mødre, med unntak av dem som hadde en kjent psykisk lidelse samt fremmedspråklige, fikk tilbud om å delta i prosjektet. EPDS innebærer en screening, og det er unødvendig å screene de man allerede kjenner. Kulturforskjeller og språkvansker kan bidra til at fremmedspråklige mødre skårer falskt positivt på screeningen.

Ved hjemmebesøk etter fødsel orienterte helsesøster mødrene om prosjektet. Orienteringen omfattet også informasjon om vanlige fødselsreaksjoner.

Etter ønske fra helsesøster utarbeidet BUP en 


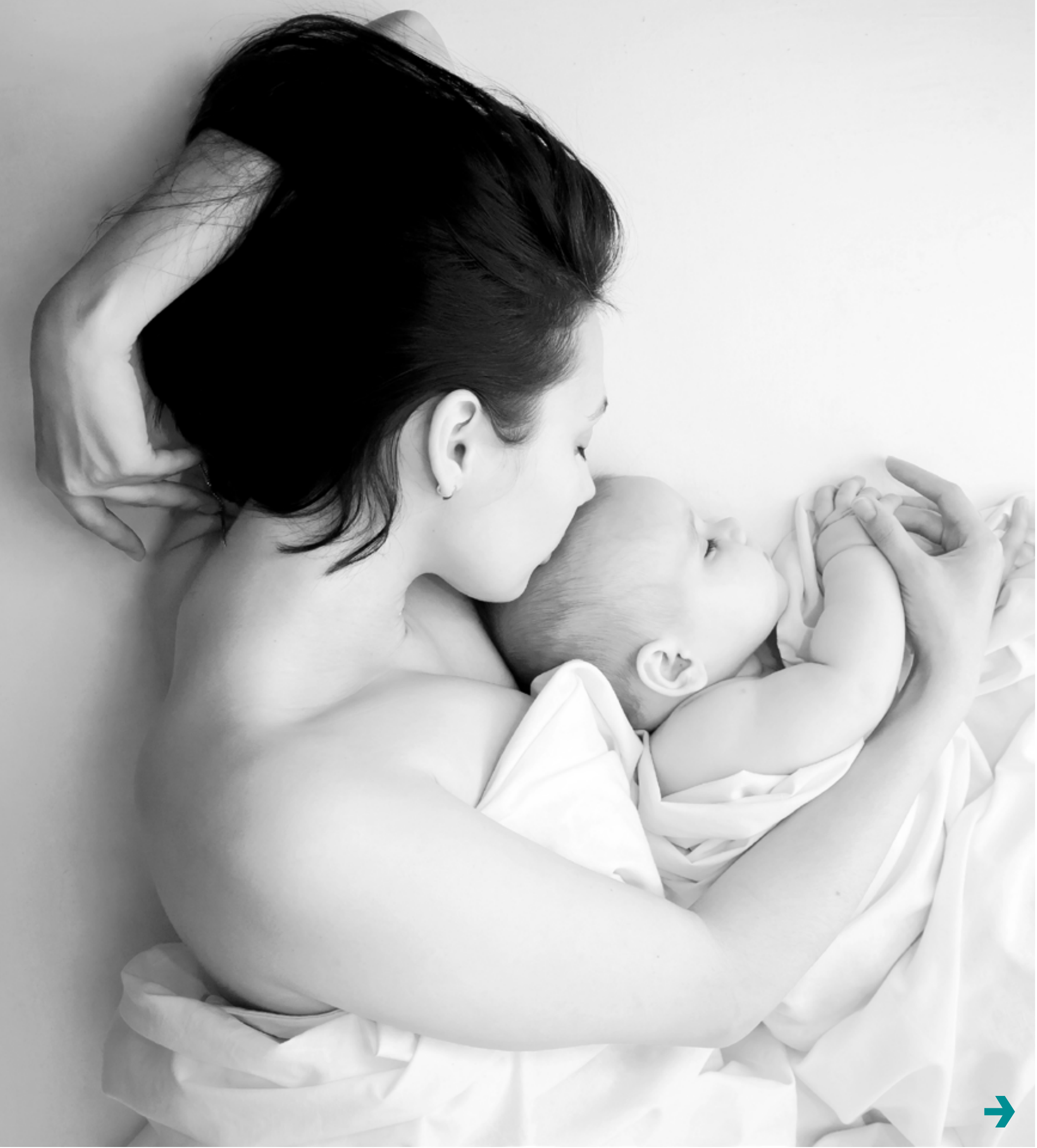


brosjyre om vanlige fødselsreaksjoner. Brosjyren ble delt ut ved første hjemmebesøk etter fødsel. Kvinnene ble forberedt på at de ved 6-ukerskontroll ville få tilbud om utfylling av EPDS og oppfølging dersom det var behov for det.

Oppfølging kunne innebære inntil fem støttesamtaler med helsesøster, samtale med en fagperson fra BUP på helsestasjonen uten henvisning, samt eventuelt videre henvisning til VOP.

\section{Resultater}

I Levanger og Inderøy var det 372 kvinner som deltok i screeningen. 14 kvinner (3,6 prosent) avslo å være med i prosjektet. Helsesøstrene fikk positiv respons på at de fokuserte på kvinners psykiske helse. Flere av helsesøstrene presiserte at de opplevde det som unaturlig å stille spørsmål om psykisk helse på sin dialekt. Det naturlige var å spørre: «Hvordan har du det da? Eller hvordan går det?».

\section{«Helsesøstre har etter hvert fått mye erfaring i å bruke metoden.»}

Slike spørsmål kunne åpne for videre samtale hvis helsesøster var sensitiv for svarene hun fikk.

Hvert svar i EPDS rangeres på en skala fra 0 til 3. Summen på hele skalaen varierer fra minimum 0 til maksimum 30. For personer som i sum skårer 12 eller mer, anbefales det at man foretar en grundigere vurdering (7).

I Levanger og Inderøy skåret 13 kvinner (3,5 prosent) 12 eller mer. Gjennomsnittsskåren på EPDS var 3,51. Noen kvinner skåret lavt på EPDS, men ga likevel inntrykk av å trenge hjelp.

\section{Helsesøstrenes evaluering}

Etter gjennomført prosjekt i 2010 ble de åtte helsesøstrene fra Levanger og Inderøy som deltok bedt om å evaluere prosjektet. Dette ble gjort ved å besvare et spørreskjema. I tillegg arrangerte BUP et møte med felles utveksling av erfaringer fra prosjektperioden.

Sju av åtte vurderte opplæringen i EPDS som positiv. Seks av åtte mente at det var nyttig for dem i deres arbeid å bruke EPDS. Begrunnelsene var at skjemaet gjorde det enklere å fokusere på psykisk helse. De hadde også begynt å spørre pasientene sine mer direkte om psykisk helse. De vurderte å bruke EPDS som en kvalitetssikring i arbeidet sitt. De fremhevet også at skjemaet gjorde det lettere for kvinnene selv, på et senere tidspunkt, å ta opp psykiske plager. Innvendinger mot å bruke EPDS var at de mente de fant like mange deprimerte uten å bruke skjemaet, og at de burde få satt av mer tid på 6-ukerskontroll til å bruke EPDS.

Fem av de åtte helsesøstrene som hadde gitt støttesamtaler hadde fått positive tilbakemeldinger fra mødrene. En mor uttalte at støttesamtalen gjorde det mulig for henne å komme seg videre i livet.

Ingen av kvinnene hadde tatt imot tilbudet om fem støttesamtaler. Samtlige opplevde at en til tre samtaler hadde vært tilstrekkelig. Noen av helsesøstrene ringte til enkelte mødre for å høre hvordan det gikk, noe som ble positivt mottatt.

To av helsesøstrene var misfornøyde med veiledningen fra BUP. Begrunnelsen var at det var vanskelig å nå fram til BUP på telefon. De syntes det var positivt å ha en psykolog $\mathrm{i}$ kommunen som kunne gi veiledning i stedet for BUP.

Tre kvinner ble henvist til voksenpsykiatrien. I det ene tilfellet var ventetiden dessverre så lang at kvinnen ikke lenger var motivert da tilbudet kom.

\section{Fortsatte med EPDS}

Seks helsesøstre anbefalte at kommunen de jobbet i skulle fortsette å bruke EPDS. Inderøy og Levanger kommune har fortsatt å bruke EPDS etter at prosjektperioden er over.

Høsten 2012 ble helsesøstrene i Inderøy og Levanger kommune bedt om å vurdere bruk av EPDS på nytt. Evalueringsskjema ble gitt til ni helsesøstre som alle svarte. Seks av helsesøstrene hadde brukt EPDS siden 2008 og har gjennomført 50 eller flere screeninger hver. De fleste, sju av ni, vurderer EPDS som et nyttig hjelpemiddel som de vil anbefale andre helsesøstre å bruke. Det ble brukt betegnelser som «Et flott hjelpemiddel for å snakke om psykiske vansker. Føler at mødrene lettere ber om hjelp dersom det oppstår vansker seinere også».

Helsesøstrene kjente seg vanligvis kvalifiserte til å gi støttesamtaler. Ved behov for videre henvisning, henviser de til kommunepsykolog og fastlege. Få kvinner blir henvist til spesialisthelsetjenesten.

\section{Erfaringer fra Verdal}

Det er stort samsvar mellom erfaringene fra Verdal og de to andre kommunene, Inderøy og Levanger. I Verdal deltok 78 kvinner i prosjektet, kun tre kvinner takket nei.

De fleste mødrene oppnådde lave skår. Det var kun tre kvinner, 3,7 prosent, som skåret 12 eller mer.

I Verdal konkluderte man: «De to jordmødrene og helsesøstrene som deltok i prosjektet mener at EPDS er et nyttig hjelpemiddel for å finne de gravide/mødrene som kan stå i fare for å utvikle depresjon. Erfaringer viser at Verdal kommune bør ta i bruk metoden i alle distrikter. Utvidet tid ved aktuelle konsultasjoner er nødvendig».

\section{Konklusjon}

Etter at prosjektperioden var avsluttet har de tre kommunene, Levanger, Inderøy og Verdal besluttet å bruke EPDS ved 6-ukerskontroll. Jordmødre som deltok i opplæringen bruker EPDS ved behov.

Helsesøstrene finner færre som skårer så høyt i EPDS at de må henvises videre til spesialist enn de hadde forventet; cirka 3,5 prosent. EPDS er da ikke gitt til kvinner som har en kjent psykisk lidelse, og ikke til fremmedspråklige.

De kvinnene som hadde behov for oppfølging, og som ønsket det, fikk støttesamtaler hos helsesøster. Ut fra BUPs vurdering viste helsesøstrene mye engasjement og ønsket å hjelpe de kvinnene som hadde behov for det. For dem som trengte videre oppfølging, var det mest vanlig å henvise til kommunepsykolog eller fastlege. Få kvinner ble henvist til spesialisthelsetjenesten, de fleste fikk hjelp lokalt. Dette er i samsvar med andre undersøkelser.

Sju av ni helsesøstre vurderer EPDS som et nyttig hjelpemiddel som de anbefaler andre helsesøstre å bruke. De vurderer EPDS som et nyttig verktøy for å fokusere på barselkvinnens psykiske helse generelt. Man kan innvende at det ikke var så mange helsesøstre som deltok i prosjektet vårt, men de har etter hvert fått mye erfaring i å bruke metoden. For BUP medførte prosjektet at vi fikk bedre kjennskap til arbeidet på helsestasjonene og i kommunene, noe vi synes har vært viktig for vårt videre samarbeid. III

\section{REFERANSER}

1. CoxJL,Holden JM,Sagovsky R.Detection of postnataldepression.Development of the 10-itemEdinburgh Postnatal Depression Scale.British Journal of Psychiatry.10-item Edinburgh Postnatal Depression Scale. British Journal of Psychiatry 1987;150:782-786.

2. Berle $₫$, Aarre TF, Mykletun, A, Dahl A, et al. Screening for postnatal depression. Validation of the Norwegianversion of the Edinburgh Postnatal Depression Scale, and assessment of risk factors for postnatal depression. Journal of Affective disorders 2003; 76: 151-156.

3. Anker-Rasch C. Kvinner med fødselsdepresjon-finner vi dem? Master of Public Health. Gøteborg: Nordiska høgskolan før folkhelsovitenskap, 2005

Hearn G, Lliff A, Jones I, et al. Postnatal depression in the community. British Journal of General practice 1998; 48: 1064-0166.

5. Johanson R, Chapman G,Murray L,et al. The North Staffordshire Maternity Hospital prospectivestudy of pregnancy-associated depression. Journal of Psychosomatic Obstetric and Gynaecology 2000;21: 93-97.

6. Holden JM, Sagovsky R, Cox JL.Counseling in a general-practice setting-controlled study of health visitor in treatment of postnatal depression. British Medical Journa 1998:298:223-226.

7. WickbergB B Hwang. Counceling of postnatal depression: a controlled study on a populationbased Swedish sample. Jouma lof affectiveDisorders Cos sinnon chlong

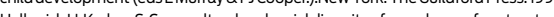
. Habrech U,Karkuns.Cross Culturaland socialdiversity of prevalence of postpartum depressionanddepressivesymptoms.Jounalof Affective Disorders 2006; 91:97-11. 10. Goodman SH, Godtlib IH. Risk for psychopatology in the children of depressed mothers; A developmental model forunderstanding mechanism of transmission. Psychological review 1999; 106: 458-490.

Fagartikler kan sendes til torhild.apall@sykepleien.no 